\title{
Evaluation of undehydrated barley feed fractions and dried oat feed fractions from integrated starch-ethanol process in diets of growing pigs
}

\author{
MATTI NÄSI and ERKKI AIMONEN \\ NÄSI, M. \& AIMONEN, E. 1992. Evaluation of undehydrated barley feed fractions \\ and dried oat feed fractions from integrated starch-ethanol process in diets of \\ growing pigs. Agric. Sci. Finl. 1: 291-301. (Univ. Helsinki, Dept. Anim. Sci., SF- \\ 00710 HELSINKI, Finland.)
}

\begin{abstract}
The nutrient digestibility and protein utilization of undehydrated barley fractions: protein (BP), protein fibre mixture (BPF) and distillers solids (DS) at two levels of inclusion in diets fortified to equal lysine content were assayed with growing pigs in a $6 \times 6$ Latin square. Dried barley fibre (BF), oat protein (OP) and oat fibre (OF) from integrated starch-ethanol production were evaluated as feed ingredients for pigs in three other trials. DS and OP had a higher essential amino acids content than BP, especially with respect to lysine. All fractions had a rather high ether extract content $46-196 \mathrm{~g} / \mathrm{kg}$ and their fatty acid composition is presented. BP showed higher protein digestibility than DS (0.931 vs. 0.857$)$ and pigs on BP-diet retained more $\mathrm{N}$ than on DS-diet. BF showed a low digestibility of $\mathrm{OM}$ and $\mathrm{CP}$ and 0.1 inclusion of $\mathrm{BF}$ mixed with $\mathrm{BP}$ depressed $\mathrm{CP}$ digestibility and $\mathrm{N}$-retention. A higher protein supply from cereal protein in the diet promoted $\mathrm{N}$-retention but decreased protein utilization. OP had high digestibility and $\mathrm{OF}$ was more digestible than BF. The study confirmed the high digestibility and energy values of the proteinous grain fractions and a high protein utilization when adequately fortified with lysine. The fibrous fractions have a rather low nutrient digestibility and their use in pig diets is therefore limited.
\end{abstract}

Key words: cereal protein, digestibility, protein utilization, nitrogen balance, pig feeding

\section{Introduction}

In Finland barley feed fractions from starch and distillery production employing an integrated process have been supplied as feedstuffs since 1987 with encouraging results and a positive response from the users. In this integrated process the majority of feed ingredients are removed before alcohol manufacturing, avoiding most of the thermal treatments common in the traditional distillery process, thus yielding feed constituents of high nutritive value. Barley has been used as the main raw material in this process, although other cereals has been monitored too. Increased barley feed fraction supply for animal feeding is expected, if the progress of fuel ethanol production schemes from cereals are realised.

Dried barley protein and distillers solubles have been shown to have high digestibility and fortified with lysine, serve as good protein supplement in pig feeding (NÄSI 1989, 1992, ALAVIUHKOLA 1989). Altough most of the feed ingredients from 
the production plant have been delivered in the undehydrated form, no evaluation of the these wet feeds has been performed. The wet form is usually more economical within a reasonable transport distance from the manufacture because drying costs are avoided and the possible detrimental thermal effects can be avoided. When there are soluble carbohydrates and amino acids present, these can react during the drying prosess and form Maillard reaction products, which are largely unavailable, and have been shown to be present in distillery products (NÄSı 1985, 1989).

Oats is the second most important crop in Finland and oats cultivation has been substituted for barley to a large extent, while at the same time the surplus of oats has still increased. However since no previous studies have been carried out in this area the suitability of oats in starch-ethanol process is unknown. Oat protein has a promising amino acid composition, which makes it interesting to evaluate its value as a protein supplement in pig nutrition. Oat products have also aroused much attention among human nutritionists, since it has been demonstrated that oat bran provides a significant hypocholesterolaemic effect (CHEN and ANDERSEN 1986).

Cereal protein obtained after the starch and ethanol process (NÄSI 1988, 1989, 1992) has a rather low quality of protein considering the degree to which the composition of the absorbed amino acids is in accordance with that required by the pig. The amino acid composition of barley protein can be improved as a protein source for pig feeding by fortification with pure amino acids, especially with lysine (NÄSı 1989, 1992).

The present paper reports the experiments which were conducted to determine and confirm the nutritive value of undehydrated barley feed ingredients from starch-ethanol production and those of dried oat feed products and barley fibre for growing pigs.

\section{Material and methods}

Feed ingredients from barley and oats used in pig trials were obtained from the Alko Ltd Koskenkorva factory employing the ordinary integrated starch-ethanol process, except the barley protein and fibre mixture, which was manufactured without the separation of protein and fibre fractions in the production plant of Alko Ltd Rajamäki. The detailed description of the process employing the integrated starch-ethanol production method has been presented by Näsı (1988). The flow-chart of the process is shown in Figure 1. In the first experiment barley fractions of barley protein (BP), mixture (BPF) in the proportion of BP 0.9 and barley fibre (BF) 0.1 and barley-starch distillers solids (DS) obtained after centrifugation of distillers solubles, were delivered undehydrated and preserved with sodiumbenzoate, $2 \mathrm{~g} / \mathrm{kg}$. They were well preserved and had pH-values of $3.89,3.93$ and 4.56 , respectively. Those lots were freeze-stored during the experimental period to ensure the stability. Barley fibre (BF) was dried, pelleted and supplemented prior to drying with $50 \mathrm{~g} / \mathrm{kg}$ sugar beet molasses, corresponding to a proportion of 0.1 of molasses in the final product, to improve palatability. The oat feed fractions were manufactured similarly as those from barley, but prior to the process oats was dehulled.

Eleven dietary treatments were used in four separate trials for nutritive value assays as outlined in Table 1. In the first experiment undehydrated barley protein, barley protein and barley fibre mixture and distillers solids were included at two levels of supplement isonitrogenously in the barley based diets to supply 160 and $181 \mathrm{~g}$ of crude protein fortified with pure lysine to $8.5 \mathrm{~g} / \mathrm{kg}$. The trial was designed as a $6 \times 6$ balanced Latin square with growing pigs which were castrated males (Landrace $x$ Large White) with an average initial weight of 31.9 (SE 3.86) $\mathrm{kg}$ and a final average weight of 96.7 (SE $4.19) \mathrm{kg}$. Two pigs outside the square were reserve animals and they were used for basic feed evaluation. As a succession dried barley fibre was assayed at two levels of inclusion in a change over trial (Exp. 2) following the first experiment with the same eight pigs at live weight from 98 to $114 \mathrm{~kg}$. Oat protein as a protein supplement was evaluated at two levels of inclusion in the barley diet with four pigs at live weight from 63.4 to $88.4 \mathrm{~kg}$ (Exp. 


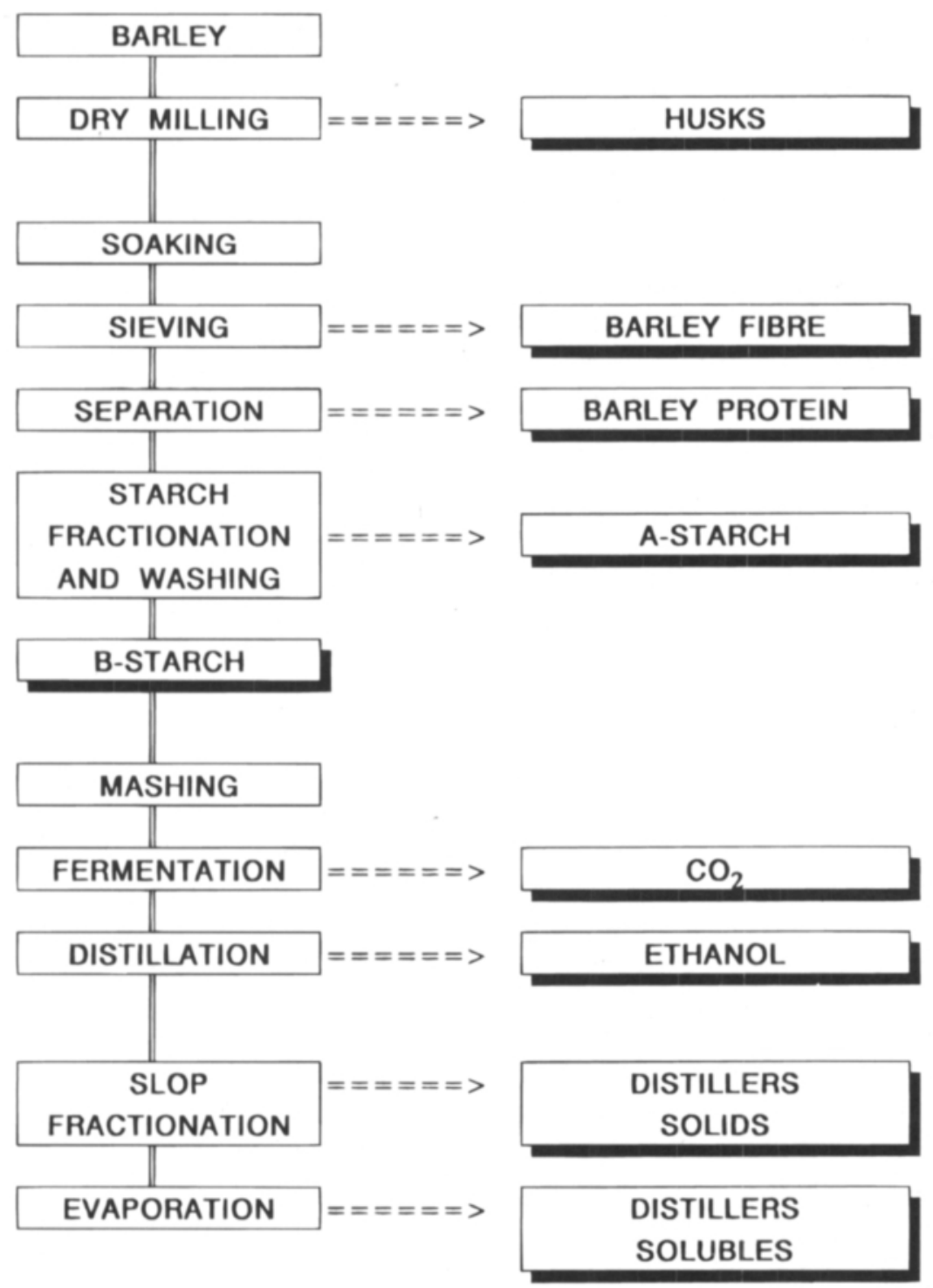

Fig. 1. The flow-chart of the intergrated starch-ethanol process and the stages at which the feed fractions are recovered. 
3). Oat fibre digestibility was measured as a sole diet component supplemented with minerals in four pigs at average live weight of $85 \mathrm{~kg}$ (Exp. 4).

The pigs were kept during the whole experiment in metal metabolism cages equipped with collection trays allowing separate collection of faeces and urine. Each period comprised 5 days of adjustment and 5 days of total collection of faeces and urine. The pigs were fed twice daily according to a restricted feeding regime and their diets were adequately fortified with minerals and vitamins (SALO et al. 1982). The details of the procedure are the same as described by NÄSI (1984). All animals completed the experiment successfully and the average daily gain during the test was $857 \mathrm{~g}$ in first experiment. The feeds were analyzed by standard methods. Neutral detergent fibre (NDF) and acid detergent fibre (ADF) were assayed according to Goering and VAn Soest (1970). Amino acids and fatty acids were determined by high-performance liquid chromatography and gas chromatography in the research laboratory of Alko Ltd.

The digestibilities of the ingredients were calculated with a regression equation from the quantities of each feed consumed and the digestion coefficients of the diets (SCHNEIDER and FLATT 1976) or by difference using separate data for basic feeds. Pig response to graded levels of the supplemental grain protein fractions was assessed in terms of nitrogen $(\mathrm{N})$ balance, urinary $\mathrm{N}$ and urea excretion, biological value and daily gain. The results were analyzed by the analysis of variance for a Latin Square. The sums of squares for treatment effect were further separated into single degrees of freedom for comparisons of the dietary treatments: protein sources and levels in diet (SNEDECOR and COCHRAN 1967).

Table 1. The outline of the experimental design and diet composition.

Experiment 1 .

\begin{tabular}{|c|c|c|c|c|c|c|}
\hline $\begin{array}{l}\text { DIET No } \\
\text { Protein supplement }\end{array}$ & $\begin{array}{l}1 \\
\mathrm{BP}(1)\end{array}$ & $\begin{array}{l}2 \\
\mathrm{BP}(2)\end{array}$ & $\begin{array}{l}3 \\
\text { BPF (1) }\end{array}$ & $\begin{array}{l}4 \\
\text { BPF (2) }\end{array}$ & $\begin{array}{l}5 \\
\text { DS (1) }\end{array}$ & $\begin{array}{l}6 \\
\text { DS (2) }\end{array}$ \\
\hline Barley g/kg & 877 & 753 & 818 & 622 & 936 & 872 \\
\hline \multicolumn{7}{|l|}{ Protein supplement } \\
\hline Barley protein, g/kg & 124 & 247 & - & - & - & - \\
\hline Barley prot.+fibre, $\mathrm{g} / \mathrm{kg}$ & - & - & 189 & 378 & - & - \\
\hline Distillers solids, $\mathrm{g} / \mathrm{kg}$ & - & - & - & - & 64 & 128 \\
\hline Total protein sypply $\mathrm{g} / \mathrm{kg}$ & 160 & 181 & 160 & 181 & 160 & 181 \\
\hline \multicolumn{7}{|l|}{ Lysine supplement } \\
\hline Crystalline lysine $\mathrm{g} / \mathrm{kg}$ & 3.68 & 3.01 & 3.43 & 2.48 & 3.01 & 1.66 \\
\hline Total lysine supply $\mathrm{g} / \mathrm{kg}$ & 8.5 & 8.5 & 8.5 & 8.5 & 8.5 & 8.5 \\
\hline
\end{tabular}

Experiments 2,3 and 4.

\begin{tabular}{|c|c|c|c|c|c|}
\hline \multirow{3}{*}{$\begin{array}{l}\text { DIET No } \\
\text { Grain fraction }\end{array}$} & \multicolumn{2}{|c|}{ Exp. 2 . } & \multicolumn{2}{|c|}{ Exp. 3 . } & \multirow{2}{*}{$\begin{array}{l}\text { Exp. } 4 \\
11\end{array}$} \\
\hline & 7 & 8 & 9 & 10 & \\
\hline & BF (1) & BF (2) & OP (1) & OP (2) & OF \\
\hline Barley g/kg & 800 & 600 & 850 & 700 & 0 \\
\hline \multicolumn{6}{|l|}{ Protein supplement } \\
\hline Barley fibre, $\mathrm{g} / \mathrm{kg}$ & 200 & 400 & - & - & - \\
\hline Oat protein, $\mathrm{g} / \mathrm{kg}$ & - & - & 150 & 300 & - \\
\hline Oat fibre, $\mathrm{g} / \mathrm{kg}$ & - & - & - & - & 1000 \\
\hline \multicolumn{6}{|l|}{ Lysine supplement } \\
\hline Crystalline lysine $\mathrm{g} / \mathrm{kg}$ & 3.00 & 3.00 & - & - & - \\
\hline
\end{tabular}




\section{Results and discussion}

\section{Composition of the grain fractions}

The chemical composition of the barley and oat feed fractions obtained from the integrated starchethanol process are presented in Table 2 . The proximate composition of the various ingredients corresponds rather well with the previous data referred to by NÄSI $(1988,1989)$, which considered the feed originating from a pilot plant production. Starch was left in the proteinous fractions $300-400 \mathrm{~g} / \mathrm{kg}$ $\mathrm{DM}$, which is a little higher than in the earlier analysis (NÄSI 1988). B-glucan contents of the ingredients were 27,19 and $9 \mathrm{~g} / \mathrm{kg}$ in $\mathrm{BP}$, in $\mathrm{BF}$ and in DS, respectively. A much higher value, $118 \mathrm{~g} / \mathrm{kg}$ $\mathrm{DM}$, was found in OF, which was obtained without using any supplemental enzyme during the process (Unpublished.). Oats have been reported to contain a high proportion of soluble fibre mainly as B-glucans (Frölich and Nyman 1988, Aspinall and
Carpenter 1984). Bach KnUdsen and Hansen (1991) found an oat bran product to compose much, $98 \mathrm{~g} / \mathrm{kg} \mathrm{B-glucans,}$ rather similar to the present $\mathrm{OF}$ product.

The amino acid composition of BP and BF was inferior compared to those of fractions received from oats revealing the protein quality of the grain raw material. Oat protein concentrates produced by a wet-milling process have been previously shown to contain lysine $39-41 \mathrm{~g} / \mathrm{kg}$ protein and total sulphur amino acids 33-43 g/kg CP (WU et al. 1973). Considerably lower values were found in oat protein concentrate obtained by alkali extraction, lysine $34 \mathrm{~g}$ and sulphur-amino acids of $34 \mathrm{~g} / \mathrm{kg} \mathrm{CP}$ (DELISLE et al. 1991). Distillers solids also had a richer essential amino acid content than other barley fractions in this study. This may be explained by the changes in the process used at the moment, in which barley solubles is not separated but it is directed in mashing. NÄsI $(1988,1989)$ found a higher lysine content in barley molasses than in BP.

Table 2. The chemical composition of the experimental feeds.

\begin{tabular}{|c|c|c|c|c|c|c|}
\hline $\begin{array}{l}\text { Feedstuff } \\
\text { Composition }\end{array}$ & $\begin{array}{l}\text { Barley } \\
\text { protein }\end{array}$ & $\begin{array}{l}\text { Barley } \\
\text { protein } \\
+ \text { fibre }\end{array}$ & $\begin{array}{l}\text { Distillers } \\
\text { solids }\end{array}$ & $\begin{array}{l}\text { Barley } \\
\text { fibre }\end{array}$ & $\begin{array}{l}\text { Oat } \\
\text { protein }\end{array}$ & $\begin{array}{l}\text { Oat } \\
\text { fibre }\end{array}$ \\
\hline Dry matter, g/kg & 231 & 237 & 151 & 878 & 967 & 887 \\
\hline Ash, $\mathrm{g} / \mathrm{kg} \mathrm{DM}$ & 39 & 46 & 48 & 39 & 20 & 42 \\
\hline Crude protein " & 312 & 248 & 470 & 200 & 408 & 237 \\
\hline Ether extract " & 46 & 56 & 134 & 75 & 196 & 105 \\
\hline Crude fibre " & 14 & 48 & 26 & 140 & 9 & 46 \\
\hline Starch “ & 402 & 328 & 83 & 118 & 297 & 328 \\
\hline Total sugars “ & 75 & 75 & 31 & 66 & 13 & 30 \\
\hline Neutral detergent fibre & & 180 & & 515 & 14 & 304 \\
\hline Acid detergent fibre & & 47 & & 154 & & 46 \\
\hline \multicolumn{7}{|l|}{ Amino acids, $\mathrm{g} / 160 \mathrm{~g} \mathrm{~N}$} \\
\hline Lysine & 30 & 36 & 47 & 43 & 43 & 64 \\
\hline Threonine & 36 & 38 & 48 & 41 & 33 & 38 \\
\hline Methionine & 23 & 24 & 25 & 22 & 19 & 20 \\
\hline Cystine & 38 & 41 & 29 & 33 & 24 & 25 \\
\hline Histidine & 19 & 20 & 24 & 7 & 28 & 26 \\
\hline Leucine & 70 & 67 & 74 & 71 & 94 & 87 \\
\hline Isoleucine & 41 & 38 & 46 & 43 & 55 & 49 \\
\hline Phenylalanine & 57 & 52 & 53 & 52 & 72 & 60 \\
\hline Arginine & 43 & 43 & 43 & 57 & 84 & 85 \\
\hline Serine & 43 & 45 & 53 & 47 & 63 & 66 \\
\hline Valine & 52 & 52 & 58 & 57 & 65 & 66 \\
\hline
\end{tabular}


The dried distillers solubles had decreased lysine and other essential amino acids compared to BP (NÄSI 1988, 1989) or to the present DS product without drying indicating some detrimental effects in the drying process.

All the grain feed fractions had a rather high ether extract content, 46-196 g/ kg DM, and this has an augmenting effect on energy content of these feeds. However the high content of unsaturated fatty acids of the lipids may also have some effects on pig carcase quality (NÄSI 1989) and rumen digestive function (HUHTANEN 1991). There is no previous data concerning the fatty acid profile of feed fractions from the integrated starch-ethanol process. The fatty acid composition of the present ingredients is presented in Table 3 . The relations of different fatty acids revealed well that of the lipids in the grain raw material used. Distillers solids showed a lower ether extract content than the total fatty acid sum, which is difficult to explain, but may be attributed to the different hydrolysis methods used prior to the analysis of fatty acids and ether extract. A high fat content in oat protein con- centrate, $101-177 \mathrm{~g} / \mathrm{kg}$, has also been reported by WU et al. (1973).

\section{Digestibility and feed values}

The digestibilities of the different diets are presented in Table 4. All the barley feed fractions seemed to be palatable to the pigs even at the higher levels of inclusion. Oat fibre was an exception, and the daily allowance had to be reduced after a preliminary period. Various amounts of ingredients were incorporated in the diets which make the comparison of diets' digestibility rather complicated. Diet protein level had an improving effect on protein digestibility $(\mathrm{P}<0.05)$. Nutrient digestibilities, obtained for barley assayed as sole diet supplemented with minerals or calculated by regression from diet digestibilities fed at two levels, were close to each other: OM 0.846 vs 0.846 (SD 0.0022); CP 0.794 vs 0.799 (SD 0.0082); EE 0.485 vs. 0.437 (SD 0.0239); CF 0.207 vs 0.262 (SD 0.038) and NFE 0.913 vs 0.911 (SD 0.0027).

The digestibilities and calculated feed values of

Table 3. The fatty acid composition of the experimental feeds.

\begin{tabular}{|c|c|c|c|c|c|}
\hline Feedstuff & $\begin{array}{l}\text { Barley } \\
\text { protein }\end{array}$ & $\begin{array}{l}\text { Barley } \\
\text { fibre }\end{array}$ & $\begin{array}{l}\text { Distillers } \\
\text { solids }\end{array}$ & $\begin{array}{l}\text { Oat } \\
\text { protein }\end{array}$ & $\begin{array}{l}\text { Oat } \\
\text { fibre }\end{array}$ \\
\hline \multicolumn{6}{|l|}{ Fatty acid, g/kg DM } \\
\hline Hexanoic $\mathrm{C}_{6: 0}$ & 0.011 & 0.010 & 0.0 & 0.081 & 0.013 \\
\hline Heptanoic $\mathrm{C}_{7: 0}$ & 0.002 & 0.002 & 0.0 & 0.0 & 0.002 \\
\hline Octanoic $\mathrm{C}_{8.0}$ & 0.002 & 0.002 & 0.03 & 0.026 & 0.004 \\
\hline Nonanoic $\mathrm{C}_{9.0}$ & 0.002 & 0.003 & 0.0 & 0.022 & 0.003 \\
\hline Decanoic $\mathrm{C}_{10: 0}$ & 0.002 & 0.002 & 0.11 & 0.0 & 0.003 \\
\hline Undecanoic $\mathrm{C}_{11: 0}$ & 0.001 & 0.001 & 0.0 & 0.037 & 0.001 \\
\hline Dodecanoic $\mathrm{C}_{12: 0}$ & 0.002 & 0.002 & 0.16 & 0.151 & 0.001 \\
\hline Tetradecanoic $\mathrm{C}_{14: 0}$ & 0.144 & 0.217 & 0.61 & 0.267 & 0.126 \\
\hline Hexadecanoic $\mathrm{C}_{16: 0}$ & 6.981 & 12.462 & 47.06 & 17.468 & 9.657 \\
\hline Octadecanoic $\mathrm{C}_{18: 0}$ & 0.606 & 0.904 & 3.31 & 1.706 & 0.908 \\
\hline Eicosanoic $\mathrm{C}_{20: 0}$ & 0.010 & 0.882 & 0.12 & 0.068 & 0.053 \\
\hline${ }^{9}$ Octadecanoic $\mathrm{C}_{18: 1}$ & 4.186 & 10.771 & 20.53 & 35.071 & 27.994 \\
\hline 9,12 Octadecadienoic $\mathrm{C}_{18: 2}$ & 18.926 & 40.286 & 79.82 & 39.285 & 27.322 \\
\hline $9,12,15$ Octadecatrienoic $\mathrm{C}_{18.3}$ & 0.0 & 0.0 & 8.29 & 0.0 & 0.0 \\
\hline Total & 30.877 & 65.544 & 160.04 & 94.182 & 66.087 \\
\hline Ether extract & 50 & 85 & 130 & 155 & 126 \\
\hline Fatty acids/ether extract & 0.618 & 0.771 & 1.229 & 0.608 & 0.525 \\
\hline
\end{tabular}


Table 4. The digestibilities of the experimental diets.

Experiment 1.

\begin{tabular}{|c|c|c|c|c|c|c|c|c|c|}
\hline $\begin{array}{l}\text { DIET No } \\
\text { Prot.supplement }\end{array}$ & $\begin{array}{l}1 \\
\mathrm{BP}(1)\end{array}$ & $\begin{array}{l}2 \\
\text { BP (2) }\end{array}$ & $\begin{array}{l}3 \\
\text { BPF (1) }\end{array}$ & $\begin{array}{l}4 \\
\text { BPF (2) }\end{array}$ & $\begin{array}{l}5 \\
\text { DS (1) }\end{array}$ & $\begin{array}{l}6 \\
\text { DS (2) }\end{array}$ & SEM & \multicolumn{2}{|c|}{$\begin{array}{l}\text { Significant effect of } \\
\text { Prot. source Prot. level }\end{array}$} \\
\hline \multicolumn{10}{|l|}{ Digestibility } \\
\hline Organic matter & 0.860 & 0.869 & 0.843 & 0.841 & 0.843 & 0.850 & 0.0032 & $* * *$ & $*$ \\
\hline Ash & 0.497 & 0.519 & 0.467 & 0.485 & 0.481 & 0.523 & 0.0112 & NS & $* *$ \\
\hline Crude protein & 0.836 & 0.853 & 0.817 & 0.835 & 0.793 & 0.804 & 0.0057 & $* * *$ & * \\
\hline Ether extract & 0.562 & 0.611 & 0.531 & 0.571 & 0.547 & 0.610 & 0.0096 & NS & $* * *$ \\
\hline Crude fibre & 0.228 & 0.227 & 0.210 & 0.234 & 0.259 & 0.309 & 0.0166 & ** & NS \\
\hline NFE & 0.918 & 0.922 & 0.907 & 0.901 & 0.907 & 0.913 & 0.0020 & $* * *$ & * \\
\hline
\end{tabular}

Exreriments 2, 3 and 4.

\begin{tabular}{|c|c|c|c|c|c|c|c|c|c|}
\hline & Exp. & & & & Exp. 3 & & & & Exp. 4 . \\
\hline $\begin{array}{l}\text { DIET No } \\
\text { Grain fraction }\end{array}$ & $\begin{array}{l}7 \\
\mathrm{BF}(1)\end{array}$ & $\begin{array}{l}8 \\
\text { BF (2) }\end{array}$ & SEM & $\begin{array}{l}\text { Signific. } \\
\text { of differ. }\end{array}$ & $\begin{array}{l}9 \\
\text { OP (1) }\end{array}$ & $\begin{array}{l}10 \\
\text { OP (2) }\end{array}$ & SEM & $\begin{array}{l}\text { Signific. } \\
\text { of differ. }\end{array}$ & $\begin{array}{l}11 \\
\text { OF }\end{array}$ \\
\hline \multicolumn{10}{|l|}{ Digestibility } \\
\hline Organic matter & 0.792 & 0.740 & 0.0036 & $* * *$ & 0.866 & 0.883 & 0.0077 & NS & 0.813 \\
\hline Ash & 0.384 & 0.359 & 0.0107 & NS & 0.441 & 0.484 & 0.0310 & NS & 0.276 \\
\hline Crude protein & 0.796 & 0.774 & 0.0065 & NS (o) & 0.841 & 0.877 & 0.0090 & NS & 0.810 \\
\hline Ether extract & 0.505 & 0.505 & 0.0140 & NS & 0.747 & 0.835 & 0.0070 & * & 0.422 \\
\hline Crude fibre & 0.225 & 0.201 & 0.0156 & NS & 0.231 & 0.221 & 0.0539 & NS & 0.269 \\
\hline NFE & 0.864 & 0.820 & 0.0020 & $* * *$ & 0.923 & 0.932 & 0.0045 & NS & 0.929 \\
\hline
\end{tabular}

NS (non-significant), ${ }^{*} \mathrm{P}<0.05,{ }^{* *} \mathrm{P}<0.01,{ }^{* * *} \mathrm{P}<0.001,(\mathrm{o} \mathrm{P}<0.1)$

the feed fractions of barley and oats are shown in Table 5. BP showed higher protein digestibility than DS but organic matter and ether extract digestibilities were quite similar in both protein sources. DS undergoes various processes; mashing, fermenting and distilling, in which the thermal effect alters protein quality. Undehydrated feeds assayed here showed a little higher digestibility than those dried feeds previously reported by NÄsI $(1985,1989$, 1992). The drying process has evidently some detrimental effects on nutritive value.

Barley fibre had rather low digestibility, 0.583 for $\mathrm{OM}$, and already 0.1 inclusion of $\mathrm{BF}$ in mixture with $\mathrm{BP}$ decreased $\mathrm{CP}$-digestibility $(\mathrm{P}<0.01)$ compared with the pure BP. Oat protein was highly digestible and $\mathrm{OF}$ had a higher digestibility than $\mathrm{BF}$ and the difference was quite large in NDF and hemicellulose, indicating differences in composition. Oat bran and oat products derived from oat endosperm have been reported to have a high pro- portion of soluble dietary fibre in the form of mixed linked B-glucans (ASPINAL and CARPENTER 1984, BACH KNUdSEn and HANSEN 1991). This is in agreement with the value of $118 \mathrm{~g} / \mathrm{kg}$ found in this study. The reduced feed intake of diet including OF is in line with the observations that soluble DF may increase the viscosity of the intralumen contents of the gastrointestinal tract so delaying stomach emptying, increasing the transit time and reducing the absorption rate in the small intestine (JENKINS et al. 1978, Holt et al. 1979). No mixed linked B-glucans have been detected in faeces (GrAHAM et al. 1986 ) and only $0.25-0.36$ of $\beta$-glucans were recovered in terminal ileum (BACH KNUDSEN and HANSEN 1991), indicating a high digestibility. The tendency for cereal fibrous fractions to depress digestibility in part reflected the attachment of nutrients to the fibre, thus preventing enzymes approaching their substrate. Also, some nutrients may have been surrounded completely by cell walls which enzy- 
Table 5. The digestibilities and calculated feed values of the experimental feeds.

\begin{tabular}{|c|c|c|c|c|c|c|}
\hline Feedstuff & $\begin{array}{l}\text { Barley } \\
\text { protein }\end{array}$ & $\begin{array}{l}\text { Barley } \\
\text { protein } \\
\text { +fibre }\end{array}$ & $\begin{array}{l}\text { Distillers } \\
\text { solids }\end{array}$ & $\begin{array}{l}\text { Barley } \\
\text { fibre }\end{array}$ & $\begin{array}{l}\text { Oat } \\
\text { protein }\end{array}$ & $\begin{array}{l}\text { Oat } \\
\text { fibre }\end{array}$ \\
\hline \multicolumn{7}{|l|}{ Digestibility } \\
\hline Organic matter & 0.943 & 0.849 & 0.919 & 0.583 & 0.955 & 0.813 \\
\hline Ash & 0.771 & 0.661 & 0.999 & 0.217 & 0.889 & 0.075 \\
\hline Crude protein & 0.931 & 0.888 & 0.857 & 0.726 & 0.945 & 0.810 \\
\hline Ether extract & 0.889 & 0.666 & 0.878 & 0.505 & 0.950 & 0.422 \\
\hline Crude fibre & 0.062 & 0.368 & 0.734 & 0.162 & 0.134 & 0.269 \\
\hline NFE & 0.962 & 0.884 & 0.999 & 0.649 & 0.990 & 0.931 \\
\hline NDF & - & - & - & 0.423 & 0.065 & 0.808 \\
\hline $\mathrm{ADF}$ & - & - & - & 0.173 & - & 0.295 \\
\hline Hemicellulose & - & - & - & 0.529 & 0.466 & 0.900 \\
\hline \multicolumn{7}{|l|}{ Feed values } \\
\hline $\mathrm{FU} / \mathrm{kg} \mathrm{DM}$ & 1.264 & 1.127 & 1.303 & 0.774 & 1.600 & 1.066 \\
\hline $\mathrm{Kg} / \mathrm{FU}$ & 3.43 & 3.74 & 5.09 & 1.44 & 0.638 & 1.060 \\
\hline DCP,, $\mathrm{g} / \mathrm{kg} \mathrm{DM}$ & 291 & 220 & 403 & 145 & 385 & 192 \\
\hline $\mathrm{DCP}, \mathrm{g} / \mathrm{FU}$ & 230 & 195 & 309 & 188 & 240 & 180 \\
\hline ME, MJ/kg DM & 17.53 & 15.58 & 18.87 & 11.01 & 21.54 & 15.12 \\
\hline NE, MJ/kg DM & 11.27 & 9.81 & 12.27 & 6.38 & 14.27 & 9.46 \\
\hline $\mathrm{NE}, \mathrm{FU} / \mathrm{kg} \mathrm{DM}$ & 1.46 & 1.27 & 1.59 & 0.83 & 1.85 & 1.23 \\
\hline
\end{tabular}

mes could not penetrate.

The feed fractions: BP, DS, and OP had high energy values, $1.26-1.60 \quad \mathrm{FU} / \mathrm{kg} \mathrm{DM}$ and 17.5-21.5 MJ ME/kg DM, due to high nutrient digestibility and fat content. These values are comparable to the earlier data (NÄsı 1989). These feeds had also a DCP content of 300-400 g/ kg DM, high enough to supplement a cereal diet with reasonable proportion of supplement. The fibrous fractions BF and $\mathrm{OF}$ had lower FU-values and contained less DCP, which limits their possibilities in pig diets. NÄsı (1989) found the performance of pigs equal to those on a control diet when $200 \mathrm{~g} / \mathrm{kg}$ barley was replaced by BF, whereas AlaviuhKola (1990, unpublished) reported decreased performance incorporating gradually $\mathrm{BF}$ as a substitute of grain up to $120 \mathrm{~g} / \mathrm{kg}$ diet.

\section{Protein utilization}

Data on nitrogen balance and protein utilization are presented in Tables 6-7. In exp. 1. the protein con- tents were 160 and $181 \mathrm{~g} / \mathrm{kg}$ diet, with similar fortified lysine supplies of $8.5 \mathrm{~g} / \mathrm{kg}$. The dietary effects were significant in several parameters of protein utilization. Barley protein compared to distillers solids led to higher nitrogen balance $(\mathrm{P}<0.01)$ and protein utilization $(\mathrm{P}<0.01)$. The reason for this was mainly lower digestibility of protein in DS $(\mathrm{P}<0.001)$ followed by a lower supply of absorbed $\mathrm{N}(\mathrm{P}<0.001)$. The daily gains of pigs were in accordance with the $\mathrm{N}$ balance being 980 and $836 \mathrm{~g}$ in BP and DS-supplemented diets, respectively. Urinary$\mathrm{N}$ and urea- $\mathrm{N}$ excretion did not differ significantly between the two protein supplements indicating similar utilization of absorbed crude protein. This agrees with production trials in growing pigs when distillers solubles in combination with BP were substituted for soybean meal (SBM) resulting in similar performance (AlaviUHKola 1989). Distillery spent wash at a level of $540 \mathrm{~g} / \mathrm{kg}$ diet DM has also given a similar performance in growing pigs to that obtained with an equal nutrient supply from a barley-SBM diet (PEERS et al. 1978). 
Table 6. The effect of different barley protein sources on the protein metabolism in pigs. Experiment 1.

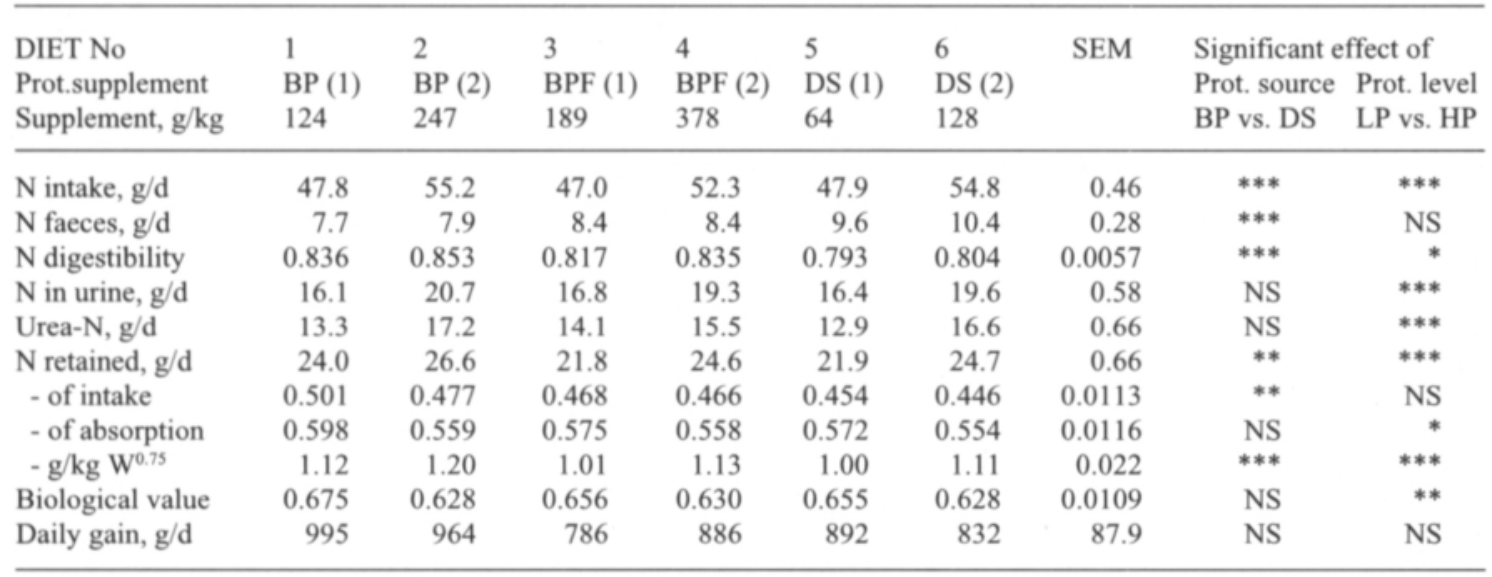

NS (non-significant), ${ }^{*} \mathrm{P}<0.05,{ }^{* *} \mathrm{P}<0.01,{ }^{* * *} \mathrm{P}<0.001$

Table 7. The effect of different barley and oat protein and fibre sources the protein metabolism in pigs. Experiments 2,3 and 4.

\begin{tabular}{|c|c|c|c|c|c|c|c|c|c|}
\hline $\begin{array}{l}\text { DIET No } \\
\text { Prot.supplement } \\
\text { Grain fraction, } \mathrm{g} / \mathrm{kg}\end{array}$ & $\begin{array}{l}\text { Exp. } 2 . \\
7 \\
\text { BF (1) } \\
200\end{array}$ & $\begin{array}{l}8 \\
\mathrm{BF}(2) \\
400\end{array}$ & SEM & $\begin{array}{l}\text { Signific. } \\
\text { differ. }\end{array}$ & $\begin{array}{l}\text { Exp. } 3 . \\
9 \\
\text { OP (1) } \\
150\end{array}$ & $\begin{array}{l}10 \\
\text { OP (2) } \\
300\end{array}$ & SEM & $\begin{array}{l}\text { Signific. } \\
\text { of differ. }\end{array}$ & $\begin{array}{l}\text { Exp.4 } \\
11 \\
\text { OF } \\
1000\end{array}$ \\
\hline$N$ intake, $g / d$ & 51.2 & 56.5 & 0.10 & *** & 69.4 & 89.5 & 1.61 & * & 33.3 \\
\hline $\mathrm{N}$ faeces, g/d & 10.5 & 12.8 & 0.35 & ** & 11.1 & 11.1 & 1.04 & NS & 6.3 \\
\hline $\mathrm{N}$ digestibility & 0.796 & 0.774 & 0.0065 & NS (o) & 0.841 & 0.877 & 0.0090 & NS & 0.810 \\
\hline $\mathrm{N}$ in urine, $\mathrm{g} / \mathrm{d}$ & 19.1 & 21.8 & 0.67 & * & 35.6 & 31.8 & 1.94 & NS & 19.3 \\
\hline Urea-N, g/d & - & - & & & 31.3 & 34.7 & 1.21 & NS & 15.8 \\
\hline $\mathrm{N}$ retained, $\mathrm{g} / \mathrm{d}$ & 21.7 & 22.0 & 0.87 & NS & 22.8 & 46.6 & 1.24 & ** & 7.7 \\
\hline - of intake & 0.423 & 0.389 & 0.0161 & NS & 0.327 & 0.521 & 0.0183 & ${ }^{*}$ & 0.230 \\
\hline - of absorption & 0.532 & 0.502 & 0.0176 & NS & 0.389 & 0.594 & 0.0140 & ** & 0.286 \\
\hline
\end{tabular}

NS (non-significant), ${ }^{*} \mathrm{P}<0.05,{ }^{* *} \mathrm{P}<0.01,{ }^{* * *} \mathrm{P}<0.001,(\mathrm{o} \mathrm{P}<0.1)$.

The mixture of barley protein and fibre (BPF) as a protein source led to a lower nitrogen balance $(\mathrm{P}<0.01)$ compared to a barley protein supplemented diet. This was mainly a consequence of the lower digestibility of protein in $\mathrm{BPF}(\mathrm{P}<0.01)$ compared to BP followed by a lower supply of absorbed $\mathrm{N}(\mathrm{P}<0.001)$, resulting in daily gains of $980 \mathrm{~g}$ and $862 \mathrm{~g}$ in BP and BPF, respectively. No significant dietary effects were found in the ratios of nitrogen retention to $\mathrm{N}$ intake, $\mathrm{N}$ absorbed or urinary and urea-N excretion.
A higher protein supply promoted nitrogen retention. Increased protein supply with equal lysine supply had a significant effect on $\mathrm{N}$ retention $(\mathrm{P}<0.001)$ as a consequence of increased $\mathrm{N}$ digestibility $(\mathrm{P}<0.05)$ and amount of absorbed $\mathrm{N}$ $(\mathrm{P}<0.001)$. The higher $\mathrm{N}$ supply led to a increased urinary $\mathrm{N}$ and urea- $\mathrm{N}$ excretion $(\mathrm{P}<0.001)$ and decreased protein utilization $(\mathrm{P}<0.05)$ and biological value $(\mathrm{P}<0.01)$, indicating an imbalanced essential amino acid profile of the feed protein. However, no effect was noticed in daily gain in 
relation to protein supply. The decreased protein utilization in relation to higher $\mathrm{N}$ supply is in accordance with the observation that there is a linear response of $\mathrm{N}$-retention, urinary and urea- $\mathrm{N}$ excretion and daily gain $(\mathrm{P}<0.001)$ to lysine supplemental level from 5.5 to $8.5 \mathrm{~g} / \mathrm{kg}$ in an isonitrogenous 160 $\mathrm{g} / \mathrm{kg}$ barley-BP diet, as demonstrated by NÄsI (1992). No interactions between the protein supplements and protein levels in diets were noticed in this trial.

Barley fibre increased the amount of $\mathrm{N}$ excreted in faeces and tended to decrease $\mathrm{N}$ digestibility $(\mathrm{P}<0.06)$, while urinary- $\mathrm{N}$ output also rose as a consequence of increased $\mathrm{N}$ supply in exp. 2 . The level of BF in the diet, however, did not have a significant effect on $\mathrm{N}$ retention or parameters of protein utilization. The diets including 200 and 400 $\mathrm{g} / \mathrm{kg}$ of BF were composed of 268 and $322 \mathrm{~g} / \mathrm{kg}$ $\mathrm{NDF}$ and 69 and $90 \mathrm{~g} / \mathrm{kg} \mathrm{ADF}$, respectively. A food such as bran rich in structural polysaccharides has been found to depress the apparent digestibility of nitrogen in some studies (KEYS and DE BARTHE 1974, Graham et al. 1986, Sauer et al. 1991). Some non-structural polysaccharides such as guar gum have been found generally to be without significant effect (HuISMAN et al. 1985). The decrease in $\mathrm{CP}$ digestibility resulting from the addition of fibre in diet is partly due to an increase in the amount of bacterial $\mathrm{N}$ voided in faeces, where bacterial $\mathrm{N}$ contributes 0.5-0.9 of total N (SAUER et al. 1991).

Some analytical errors exist in the assay of oat protein utilization, especially in urinary- $\mathrm{N}$, which give a $\mathrm{N}$ retention of unrealistic value. The nutritive value of oat protein has been reported to be higher than of any other cereal protein (RoBbins et al. 1971) due to the promising essential amino acid composition (Table 2). Oat protein concentrate $(659 \mathrm{~g} / \mathrm{kg} \mathrm{CP})$ obtained by alkali extraction has been used as an alternative protein source in milk replacers for piglets and could replace up to 0.5 of milk proteins without an apparent detrimental effect on DM intake and $\mathrm{N}$ digestibility, however growth rate was reduced a little (DELISLE et al. 1991).

The present experiments, performed to assess the nutritive value of barley feed fractions, confirmed the earlier data that the proteinous fractions from barley and oats produced by the present integrated starch-ethanol technology have high digestibility and energy value for pigs and, as preserved in wet form, have at least an equal value than those of dried. The data of protein utilization showed these ingredients to have a high protein value when fortified adequately with lysine. The fibrous fractions have rather low nutrient digestibility and their use in pig diets is therefore limited.

\section{References}

AlAVIUHKOLA. T. 1989. Ohravalkuaisrehu on täyttänyt odotukset. Sika 4/89: 6-7.

ASPINAlL, G.O. \& CARPENTER, R.C. 1984. Structural investigations on the non-starchy polysaccharides of oat bran. Carbohydrate Polymers 4: 271-282.

BaCH Knudsen, K.E. \& HANSEN, I. 1991. Gastrointestinal implications in pigs of wheat and oat fractions. 1. digestibility and bulking properties of polysaccharides and other major constituents. Br. J. Nutr. 65: 217-232.

Chen, W.J.L. \& ANDERSON, J.W. 1986. Hypocholesterolemic effects of soluble fibers. In: Vahouny, G.V. \& Kritchevsky, D. (eds.). In Dietary fiber, basic and clinical aspects. pp. 275-286. Ed. G.V. Vahouny and D. Kritchevsky. New York, Plenum Press.

Delisle, J., Bernier, J.F \& BRISSON, G.J. 1991. Replacing skimmed milk powder by oat protein concentrate in milk replacers for piglets. Can. J. Anim. Sci. 71: 515-521.

Frölich, W. \& NyMAN, M. 1988. Minerals, phytate and dietary fibre in different fractions of oat-grain. J. Cereal Sci. 7: 73-82.

Goering, H.K. \& VAn Soest, P.J. 1970. Forage fiber analysis: apparatus, reagents, procedures and some applications. U.S. Dep. Agric. Handb. 379: 8-9.

Graham, H., Hesselman, K. \& Ảman, P. 1986. The influence of wheat bran and sugar-beet pulp on the digestibility of dietary components in a cereal-based pig diet. J. Nutr. 116: 242-251.

Holt, S., Heading, R.C., Carter, D.C., Prescott, L.F. \& TOTHILL, P. 1979. Effect of gel fibre on gastric emptying and absorption of glucose and paracetamol. Lancent, 636-639.

Huhtanen, P. 1992. The effects of barley vs. barley fibre 
with or without distillers' solubles on site and extent of nutrient digestion in cattle fed grass silage-based diets. Anim. Feed Sci. Technol. 36:319-337.

Huisman, J., Den Hartog, L.A., Boer, H., Van Wergden, E.J. \& THIELEN, W.J.G. 1985. The effects of various carbohydrate sources on the ileal and faecal digestibility of protein and amino acids in pigs. 3rd Intern. Sem. on Digestive Physiology in the Pig. Proc. p. 195-198.

Jenkins, D.J.A., Wolever, T.M.S., Leeds, A.R., Gassull, M.A., Haisman, P., Dilawari, J., Goff, D.V., Metz, G.L. \& AlBerti, K.G.M.M. 1978. Dietary fibers, fibre analogues and glucose tolerance: importance of viscosity. Br. Medical J. 1: 1392-1394.

KeYs, J.E. \& DE BARTHE, J.V. 1974. Cellulose and hemicellulose digestibility in the stomach, small intestine and large intestine of swine. J. Anim. Sci. 39: 53-56.

NĀsı, M. 1984. Nutritive value and metabolic effects of whey protein concentrate and hydrolysed lactose for growing pigs. J. Agric. Sci. Finl. 56: 227-238.

- 1985. Distillers' feeds from various grains as protein sources for pigs. J. Agric. Sci. Finl. 57: 255-262.

- 1988. Evaluating barley feed fractions from integrated ethanol-starch production in diets of ruminants. J. Agric. Sci. Finl. 60: 701-709.

- 1989. Barley feed fractions from integrated ethanolstarch process in diets of pigs. J. Agric. Sci. Finl. 61: 441-450.

- 1992. Protein utilization responses of growing pigs to supplemental lysine as liquid versus crystalline form in barley-barley protein diet. Agric. Sci. Finl. 1: 215-223.
Peers, D.G., Hillyer, G.M. \& Macandrew, A. 1978 The evaluation of grain distillers' evaporated spent wash in diets for growing pigs. Anim. Prod. 26: 396-397.

Robbins, G.S., Pomeranz, Y. \& Briggle, L.W. 1971. Amino acid composition of oat groats. J. Agric. Food Chem. 19: 536-539.

SAlo, M.-L., TuORI, M. \& KiISKInEN, T. 1982. Rehutaulukot ja ruokintanormit. 70 p. Helsinki.

Sauer, W.C., Mosenthin, R., Ahrens, F. \& Den Hartog, L.A. 1991. The effect of source of fiber on ileal and fecal amino acid digestibility and bacterial nitrogen excretion in growing pigs. J. Anim. Sci. 69: 4070-4077.

SCHNEIDER, B.H. \& FlATT, P.W. 1976. The evaluation of feeds through digestibility evaluation. Univ. Georgia Press. Athens. 423. p.

Snedecor, G.W. \& Cochran, W.G. 1963. Statistical methods. 7 th ed. 597 p. The Iowa state univ. Press, Ames, Iowa.

Wu, Y.V., CluSkeY, J.E., WAll, J.S. \& Inglett, G.E. 1973. Oat protein concentrates from wet-milling process: composition and properties. Cereal Chem. $50: 481-888$.

\section{Manuscript received February 1992}

Matti Näsi

Erkki Aimonen

University of Helsinki

Department of Animal Science

SF-00710 Helsinki, Finland

\title{
SELOSTUS
}

\section{Tärkkelys-etanolituotannosta saatavien kuivaamattomien ohrajakeiden ja kuivattujen kaurajakeiden arvo lihasikojen rehuna}

\author{
MAtTI NÄSı ja ERKKI AIMONEN \\ Helsingin yliopisto
}

Tutkimuksessa selvitettiin yhdistetystä tärkkelys-etanolituotannosta saatavan kuivaamattoman ohravalkuisrehun, ohravalkuis-ohrarehuseoksen ja tärkkelysrankin sekä kuivatun ohrarehun, kauravalkuisrehun ja kaurakuidun rehuarvoa lihasikojen ruokinnassa. Tuoreet rehujakeet oli săilötty natriumbentsoaatilla, $2 \mathrm{~g} / \mathrm{kg}$. Rehujakeiden ravintoaineiden sulavuutta ja valkuisen hyväksikäyttöä tutkittiin neljässă sikojen sulavuus- ja typpitasekokeessa. Rehujakeista analysoitiin normaalien koostumusmääritysten lisäksi myös aminohappojen ja rasvahappojen pitoisuudet.
Ohravalkuisrehun valkuisen sulavuus oli korkeampi kuin tärkkelysrankin ja samoin sikojen typen pidättyminen oli ohra-ohravalkuisrehudieetillä korkeampi kuin ohratärkkelysrankkidieetillä. Kauravalkuisrehun sulavuus oli korkea. Ohrarehun ravintoaineiden sulavuus oli alempi kuin kaurakuidun. Ohrarehulisäys alensi dieetin valkuisen sulavuutta ja hyväksikäyttöä. Proteiinipitoisten rehujakeiden energia-arvot olivat korkeita, 1.26-1.60 RY/kg KA, kun taas kuitupitoisten jakeiden olivat huomattavasti alempia. 